\title{
A Plea for Fairer Sharing of the True Costs of Publication
}

Citation for published version (APA):

Prevoo, M., Aardening, R., Wijk, I., \& Vines, T. (2021). A Plea for Fairer Sharing of the True Costs of Publication. Editorial Office News, 14(2), 2-5. [1]. https://doi.org/10.18243/eon/2021.14.2.1

Document status and date:

Published: 01/03/2021

DOI:

10.18243/eon/2021.14.2.1

Document Version:

Publisher's PDF, also known as Version of record

Document license:

CC BY

\section{Please check the document version of this publication:}

- A submitted manuscript is the version of the article upon submission and before peer-review. There can be important differences between the submitted version and the official published version of record.

People interested in the research are advised to contact the author for the final version of the publication, or visit the DOI to the publisher's website.

- The final author version and the galley proof are versions of the publication after peer review.

- The final published version features the final layout of the paper including the volume, issue and page numbers.

Link to publication

\footnotetext{
General rights rights.

- You may freely distribute the URL identifying the publication in the public portal. please follow below link for the End User Agreement:

www.umlib.nl/taverne-license

Take down policy

If you believe that this document breaches copyright please contact us at:

repository@maastrichtuniversity.nl

providing details and we will investigate your claim.
}

Copyright and moral rights for the publications made accessible in the public portal are retained by the authors and/or other copyright owners and it is a condition of accessing publications that users recognise and abide by the legal requirements associated with these

- Users may download and print one copy of any publication from the public portal for the purpose of private study or research.

- You may not further distribute the material or use it for any profit-making activity or commercial gain

If the publication is distributed under the terms of Article $25 \mathrm{fa}$ of the Dutch Copyright Act, indicated by the "Taverne" license above, 


\section{A Plea for Fairer Sharing of the True Costs of Publication}

\section{By Mariëlle Prevoo}

Open Knowledge Librarian

Maastricht University Library

\section{By Ron Aardening}

Scholarly Communications \& (Open Access) Publishing Officer Maastricht University Library

\section{By Ingrid Wijk}

Director

Maastricht University Library

\section{By Tim Vines}

Founder and Director

DataSeer

Editors' Note: This article is an adapted version of a blog post published on the Scholarly Kitchen.

Under open access (OA), the public has immediate access to scholarly output free of charge. In the case of author-pays Gold OA, publishers charge scholars at acceptance for publishing the results of their research. Gold OA turns the traditional library subscription business model by 180 degrees, from a consumer-paid to a supplier-paid model. Funding agencies, governments, universities, and the publishing industry are exploring ways to change scholarly publishing to OA; for example, Plan S "requires that, from 2021, scientific publications that result from research funded by public grants must be published in compliant Open Access journals or platforms".

The costs paid by authors under OA are called article processing charges (APCs). These APCs vary widely across journals, which cannot only be explained by variation in actual costs; market power plays a role there as well. ${ }^{2}$ However, the term processing charge is somewhat misleading, as authors who submit a paper that gets rejected in whatever phase of the process do not have to pay. In other words, rejected articles do not contribute to covering their processing costs. The current pricing model is analogous to a university invoicing all graduating students for both the costs of their study program and the tuition fees of their peers who dropped out along the way. That hypothetical situation would strike most as unfair, and we would like to argue here that the current APC model is equally unfair.

\section{The Current APC Model}

What is processing in this context? The publishing process can be broken down into three stages a paper can go through:

1. it starts with the submission and desk review;

2. (in case of a positive outcome) peer reviews; and

3. (if peer review was also successful, potentially after revision) further editing and publication.

Each of the stages involves editorial office staff salaries and overheads, as well as costs associated with the technologies and systems employed. There are also other costs involved for the publisher (see Van Noorden ${ }^{3}$ ). These costs, of course, need to be covered as well, but for reasons of clarity and simplicity, we do not specify them here.

Many discussions have already taken place about how APCs might lead to increased pressure on editors to accept lower quality articles to improve profits. We want to propose an alternative to the current application of APCs that benefits everyone in the scholarly publishing chain.

A high proportion of drafted manuscripts are never published and will drop out somewhere in the publishing process (e.g., only $39 \%$ of observational studies with safety outcome[s] registered on ClinicalTrials.gov were published at least 30 months after the study completion ${ }^{4}$ ). Research by Michael Kovanis and colleagues ${ }^{5}$ indicated that $15 \%$ of publications result from the first submission, $47 \%$ from the second submission, and $20 \%$ from the third submission. Many authors are using (or abusing?) the peer-review system repeatedly without paying for any of the associated processing costs. For now, most of these costs are paid by journal subscribers, but in an OA world, the costs would be covered by authors who do successfully publish in a given journal. This arrangement penalizes authors who carefully choose where to submit their work while benefitting those who employ a more scattershot approach. Authors may even be advised to use journal peer review in place of soliciting feedback from colleagues or carefully crafting the manuscript prior to submission. ${ }^{6}$ 


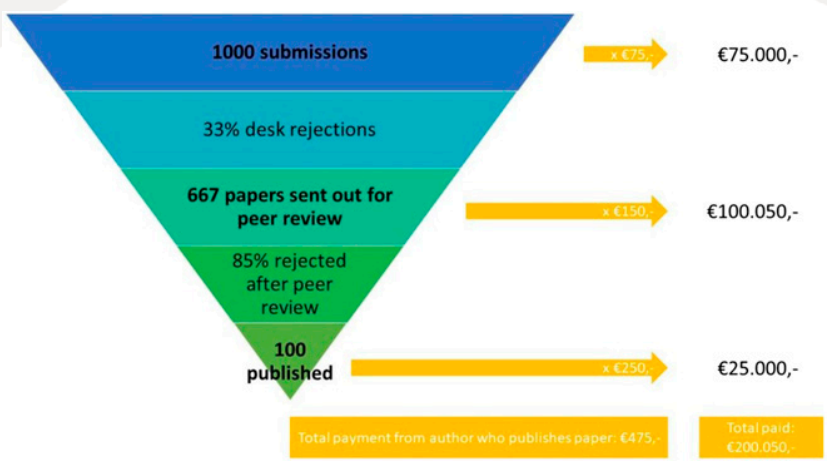

Figure 1. Example of fee structure designed to share processing and review costs more equitably.

\section{A Better APC Model}

If we look at the added value of the work done by the publisher in each phase of the publishing process, we see ways to distribute the publishing costs more fairly.

One approach is to split the APC into a submission and a publication fee, ${ }^{7-10}$ which addresses the unfairness of charging authors of published articles for the costs generated by rejected manuscripts. Here, we propose a further disentangling of these costs by adding a peer-review fee.

An example: Assume a journal publishes 100 articles, and the current APC needed to cover costs is $€ 2,000$ (total revenue of $€ 200,000$ ). Let us further assume that the desk rejection rate is $1 / 3$ and the acceptance rate (after initial desk review) is $15 \%$ (i.e., the overall acceptance rate is $67 \% \times 15 \%=10 \%$ ). A total of 1,000 papers have been submitted. To earn the same level of revenue, the publisher can charge a submission fee of $€ 75$ to all 1,000 submitting authors ( $=€ 75,000$ ); $€ 150$ for reviewing to the 670 authors whose articles were not desk rejected ( $=€ 100,500$ ) and another $€ 250$ to the 100 authors whose work was accepted for publication ( $=€ 25,000$ ). In this situation, the researcher needs to pay in total $€ 475$ if the article is published (see Figure 1), a fraction of the $€ 2,000$ APC under the current model, but the total revenue to the journal is still around $€ 200,000$. Transaction costs on the side of the publishers will increase under this new model, because more invoices need to be sent out and handled. However, even if those costs are charged to authors as well, the total costs for one published article will still be significantly lower than in the current situation. Moreover, this adapted APC model can help to avoid free-riding and aiming unrealistically high as a researcher when choosing a journal.

We know from our personal experiences as librarians that scholars only look for a budget to cover the APC once their manuscript has been accepted for publication. For high APCs, they can often feel somewhat reluctant to ask their supervisor, principal investigator, or the library how to cover the costs. In the APC model that we propose, these scholars would have to arrange a budget at the beginning of the submission phase. Having this discussion early on in the research process and include article processing costs in the research plan and budget takes some of the pressure off. Moreover, it can be seen as expectation management, because the party providing the budget knows that more costs are to be expected if and when the manuscript gets accepted.

Journals that have experimented with submission fees before found that submission numbers went down significantly $\left(33.5 \%\right.$ in the case reported by Nwachukwu et $\mathrm{al}^{11}$ ) when introducing a submission fee. A decreased number of submissions offers the benefit of reduced costs-less time and effort spent on review as well as lower usage of the often costly technologies involved. Amounts charged for various fees can be reduced to reflect these reduced costs.

It is not clear whether such a decrease in submissions would happen in a situation where the submission fee is introduced by an OA journal that is currently using a traditional OA payment system with an APC. In that situation the introduction of the submission fee would lead to a substantial reduction in charges paid for a published article, which may attract more authors, offsetting any decrease caused by the submission fee. The lower costs can strengthen a journal's competitive position as compared to other journals in the field. If a reduction in the number of submissions is still observed, however, the finding of Nwachukwu and colleagues ${ }^{11}$ that there was no change in the characteristics of submitted manuscripts is essential to take into account. If that is the case, the assumption that 1,000 submissions are needed for 100 publications remains unchanged.

\section{New Perspectives}

A shift from publication-based charging to process-based charging may lead to better allocation of scholarly communication costs, lower charges per published article, and probably also a better consideration about the choice whether to seek publication and in which journal. The time seems ripe to introduce a new APC model of this type now that the Plan $S$ requirement for authors to publish $O A$ has arrived and more and more journals are flipping to an $O A$ model. The proposed change in the APC model is also in line with the change in recognition and rewarding of researchers, leaving more room for journal choices based on factors other than a journal's Impact Factor. Moreover, Coalition S is 
seeking pricing transparency for authors, ${ }^{12}$ and our proposed structure offers precisely that.

Looking at the stakeholders that are involved in scholarly communication, there is much to gain by changing the way scholarly communication is priced. The benefits for researchers are both transparency in the prices of delivered services by a publisher and lower costs per published article. Moreover, a researcher is triggered by the new APC model to make risk assessments and decide where to submit their manuscript: will it still be in that high Impact Factor journal with a long lead time and a small chance of being published? Or will more transparency and a change in the pricing model lead to less focus on Impact Factors, making other criteria more critical when choosing an outlet? If so, this might help to shorten the time between first submission and publication, and reduce the hidden costs of rejection and the pressure on both the publishing and the peer-review process (in the example, assuming two reviewers per article, over 1,300 reviews need to be completed to end up with 100 published articles), leaving time for other important tasks.

Of course, we cannot ignore the fact that a potential roadblock in the transition to a new APC model is that journals might be less likely to introduce submission and peer-review fees if their competitors do not charge such fees. However, when the total article processing costs are taken into account, introducing these fees might be beneficial for a journal's competitiveness as it enables authors to publish $O A$ at a lower price without sacrificing quality. Because the literature on the introduction of submission fees is not (yet) based on OA journals, we cannot predict which of the two scenarios is more likely to happen: a decline in the number of submitted manuscripts or a stabilization or increase because of the lower total APC costs ahead. Tim Vines suggested to let authors choose between the new APC model (including a submission fee), or not paying a submission fee but paying a (higher) APC at acceptance of the paper. ${ }^{10}$ This suggested approach is not only a right solution for the transitional phase to the new APC model, it can also provide valuable insights into the effects of introducing a submission fee for an OA journal. We invite editors of $O A$ journals to take the plunge and offer authors the choice between the traditional APC at acceptance or our three-step APC model.

To us, changing the APC model now seems a much better idea than to wait until that ship has sailed and we end up in an OA world with undesirably high publication (as opposed to processing) charges. If you agree, join us in getting this message across to funders so they can publicly voice their support, and to publishers to help persuade them of the enormous benefits of transparency and fair pricing.

\section{Disclosure Statement}

The authors have no relationships or conflicts to disclose.

\section{References}

1. European Science Foundation. About Plan S. Accessed February 18, 2021. https://www.coalition-s.org/

2. Budzinski O, Grebel T, Wolling J, Zhang X. Drivers of article processing charges in open access. Scientometrics. 2020;124(3):2185-206. https://doi.org/10.1007/ s11192-020-03578-3

3. Van Noorden R. Open access: The true cost of science publishing. Nature. 2013;495(7442):426-9. https:// doi.org/10.1038/495426a

4. Baudart M, Ravaud P, Baron G, Dechartres A, Haneef R, Boutron I. Public availability of results of observational studies evaluating an intervention registered at ClinicalTrials.gov. BMC Med. 2016;14(1):7. https://doi.org/ 10.1186/s12916-016-0551-4

5. Kovanis M, Porcher R, Ravaud P, Trinquart L. Complex systems approach to scientific publication and peerreview system: development of an agent-based model calibrated with empirical journal data. Scientometrics. 2016;106(2):695-715. https://doi.org/10.1007/s11192015-1800-6

6. Charlesworth Author Services. How to target your research at high impact journals. March 03, 2020. Accessed February 18, 2021. https://www.cwauthors.com/article/ Highimpactjournals

7. The Wellcome Trust. Costs and business models in scientific research publishing February 2004. Accessed February 18, 2021. https://wellcome.org/sites/default/ files/wtd003184_0.pdf

8. Ware M. Submission Fees - A tool in the transition to open access? March 2010. Accessed February 18, 2021.

http://www.markwareconsulting.com/wordpress/wpcontent/uploads/2010/12/KE_Submission_fees_Short_ Report_2010-11-25-1.pdf

9. Crotty D. Can highly selective journals survive on APCs? Oct 10, 2016. Accessed February 18, 2021. https:// scholarlykitchen.sspnet.org/2016/10/10/can-highly-selectivehigh-end-journals-survive-on-apcs/

10. Vines T. Plan T: Scrap APCs and fund open access with submission fees. September 20, 2018. Accessed February 18, 
2021. https://scholarlykitchen.sspnet.org/2018/09/20/plan-tscrap-apcs-and-fund-open-access-with-submission-fees/

11. Nwachukwu BU, Schairer WW, So C, Bernstein JL, Herndon J, Dodwell ER. The Early Impact of an Administrative Processing Fee on Manuscript Submissions at The
Journal of Bone \& Joint Surgery. J Bone Joint Surg Am. 2016;98(19):e82. https://doi.org/10.2106/jbjs.15.01118

12. Wise A, Estelle L. Open access price transparency. Accessed February 18, 2021. https://www.ouvrirlascience.fr/open-accessprice-transparency-2/

\section{Call for Volunteers}

\section{Volunteers Needed for Strategic Plan Implementation}

The following ISMTE committees are in need of volunteers in 2021:

- Sponsorship Committee

- Website Committee

- Webinar Committee

- Marketing and Social Media Committee

- Asia Pacific Conference Committee

If you are interested in sharing your time and talent with ISMTE please sign up via the ISMTE Volunteer Form.

The ISMTE Board of Directors decided to have a single strategic focus for 2021-to increase engagement by editorial office professionals with ISMTE by 1,000 registrations. This goal can be achieved through attendance at webinars, virtual local groups, and conferences, among other events. We welcome your help with reaching this goal by becoming a member of an ISMTE committee. A broad range of opportunities with varying requirements of time and expertise are available. By being a member of a committee, you can help drive new programs, products, and services that benefit the profession and serve the greater community of scholarly publishing professionals. You'll also have opportunities for interaction with other editorial office professionals and enjoy personal and professional growth.

\section{Call for Submissions}

Are you a fan of EON? Do you have an idea for an article, column, or special section? Contact our editorial office today to share your suggestion or for more information on submitting a manuscript. 